\title{
Root System Morphology of Ipê-Roxo Tree Grown in Soil Subjected to Phosphorus Application in Subtropical Climate Region
}

\author{
Carolina Fogliarini Parcianello ${ }^{1}$, Álvaro Luís Pasquetti Berghetti $2, * \mathbb{C}$, Maristela Machado Araujo ${ }^{2}$, \\ Gabriel Alberto Sans ${ }^{1}{ }^{\mathbb{D}}$, Vanessa Marques Soares ${ }^{1}$, Vanessa Viera Trindade de Oliveira ${ }^{2}{ }^{\oplus}$, Vinícius Wille Alves ${ }^{2}$,

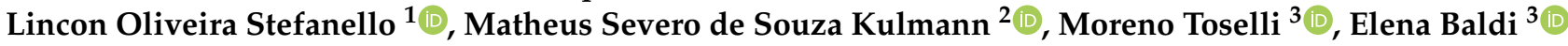 \\ and Gustavo Brunetto ${ }^{1}$
}

check for updates

Citation: Parcianello, C.F.; Berghetti,

Á.L.P.; Araujo, M.M.; Sans, G.A.; Soares, V.M.; Oliveira, V.V.T.d.; Alves, V.W.; Stefanello, L.O.; Kulmann, M.S.d.S.; Toselli, M.; et al. Root System Morphology of Ipê-Roxo Tree Grown in Soil Subjected to Phosphorus Application in Subtropical Climate Region. Agronomy 2021, 11, 1563. https://doi.org/10.3390/agronomy 11081563

Academic Editor: Miriam Edith Athmann

Received: 20 June 2021

Accepted: 3 August 2021

Published: 5 August 2021

Publisher's Note: MDPI stays neutral with regard to jurisdictional claims in published maps and institutional affiliations.

Copyright: (c) 2021 by the authors. Licensee MDPI, Basel, Switzerland. This article is an open access article distributed under the terms and conditions of the Creative Commons Attribution (CC BY) license (https:/ / creativecommons.org/licenses/by/ $4.0 /$ )
1 Soil Science Department, Federal University of Santa Maria (UFSM), Santa Maria 97105-900, RS, Brazil; carolfparcianello@gmail.com (C.F.P.); gabalbertosans@gmail.com (G.A.S.); vanessa_marquessoares@outlook.com (V.M.S.); linconfa@hotmail.com (L.O.S.); brunetto.gustavo@gmail.com (G.B.)

2 Forest Science Department, Federal University of Santa Maria (UFSM), Santa Maria 97105-900, RS, Brazil; maristela.araujo@ufsm.br (M.M.A.); vvtovanessa@gmail.com (V.V.T.d.O.); viniciuswillealves@gmail.com (V.W.A.); matheuskulmann@hotmail.com (M.S.d.S.K.)

3 Department of Agricultural and Food Sciences, University of Bologna, 40126 Bologna, BO, Italy; moreno.toselli@unibo.it (M.T.); elena.baldi7@unibo.it (E.B.)

* Correspondence: alvaro.berghetti@gmail.com

Abstract: Phosphorus (P) availability in subtropical soils does not often meet the nutritional demand of native tree species such as the ipê-roxo tree (Handroanthus heptaphyllus); therefore, it is necessary to supply $\mathrm{P}$ at planting. However, the impact of $\mathrm{P}$ on root system growth remains unknown. The aim of the current study was to investigate the effect of $\mathrm{P}$ application on root morphology of $H$. heptaphyllus plants over a 36-month period in a subtropical climate region. During the experiment, the plants subjected to fertilization with $40 \mathrm{~kg} \mathrm{P} \mathrm{ha}^{-1}$ were compared to untreated control. Plant roots were scanned through minirhizotron system 18 and 36 months after transplant (MAT), and generated images were used to determine total root length, mean root diameter and total root volume. Plant height and leaf P concentrations were also evaluated. Phosphorus application enhanced root and whole plant growth with a more evident effect at 36 MAT, when soil P availability decreased. The results give important information on the cultivation of $H$. heptaphyllus plants in soils presenting low P availability.

Keywords: forest nutrition; minirhizotron; noble wood; phosphate fertilization; root length; tree species

\section{Introduction}

Native tree species such as Handroanthus heptaphyllus (Vell.) Mattos (popularly known in Brazil as ipê-roxo tree or ipê-rosa) are often used in projects focused on reforestation processes, environmental preservation, recovery of degraded areas, urban afforestation and landscaping [1-3]. H. heptaphyllus grows quickly and presents a long cylindrical stem, high-density wood, resistance and durability [3,4]. Thus, it has great potential to be used in civil construction [5], furniture manufacturing, decorative openings and cladding [6].

The proper growth of native trees such as ipê-roxo tree, mainly in soils presenting low natural fertility, may be associated with the development of mechanisms or strategies such as root morphological modifications to increase soil exploration (cluster roots) changes in rhizospheric soil $\mathrm{pH}$ and exudation of organic acids such as malic and citric acids, among others, which increase soluble organic carbon concentration in the solution and, consequently, increase the solubilization and availability of nutrients such as phosphorus (P) $[7,8]$. However, soil-available P concentrations do not always meet plants' demands, 
especially in sites aimed at rapid wood growth and high yield $[9,10]$. Thus, it is necessary to apply phosphate fertilizers at seedling planting [10-12] to overcome this deficiency.

Phosphorus is essential to plant growth since it acts in energy storage and transfer processes. In addition, it is a structural component of the plasma membrane of cells, such as root cells, which contributes to water and nutrient absorption [13]. Most of the P applied to soils is adsorbed with high binding energy to the surface functional groups of inorganic reactive particles such as 1:1, 2:1 clay minerals, iron $(\mathrm{Fe})$, manganese $(\mathrm{Mn})$ and aluminum (Al) oxides [14], whereas a smaller part can be adsorbed with lesser binding energy and be easily available for the plant [15]. When this happens, $\mathrm{P}$ can be taken up by the root system and stimulate the increase of total root length, mean root diameter, total root volume and branching angle [16]. This happens since plant $\mathrm{P}$ homeostasis is maintained through different signaling mechanisms that perceive external inorganic $\mathrm{P}(\mathrm{Pi})$ concentrations in the environment, and it stimulates carbon investment towards capturing more resources from the soil. Thus, the higher the soil $\mathrm{P}$ availability and the volume of soil explored by roots, the higher the root uptake of water and nutrients, including different $\mathrm{P}$ forms leading to enhancement of leaf $\mathrm{P}$ concentrations and faster plant growth.

However, the real impact of phosphate fertilization on root system morphology and dynamics in tree species grown in subtropical climate regions remains poorly understood. Thus, the hypothesis of the current study is that $\mathrm{P}$ application increases available $\mathrm{P}$ levels, favors in-depth root system growth, increases $\mathrm{P}$ absorption by the roots and, consequently, improves early plant development. The aim of the current study was to evaluate root morphology in $\mathrm{H}$. heptaphyllus plants grown in soil subjected, or not, to P application in subtropical climate region.

\section{Materials and Methods}

\subsection{Experimental Site Description}

The study was carried out in Santa Maria County, Rio Grande do Sul State (RS), Southern Brazil (latitude $29^{\circ} 47^{\prime} 30^{\prime \prime}$ S, longitude 53 $39^{\prime} 47^{\prime \prime}$ W), from September 2016 to September 2019. The landscape in the experimental site is featured as smooth wavy. The climate in the region is classified as Cfa (subtropical Humid) based on Köppen's classification, and it is characterized by air temperature ranging from $-3^{\circ} \mathrm{C}$ to $18{ }^{\circ} \mathrm{C}$ in the coldest month and higher than $22^{\circ} \mathrm{C}$ in the warmest month; mean annual rainfall is $1769 \mathrm{~mm}$, and rainfall events are well distributed throughout the year [17]. Air temperature and mean monthly rainfall rates during the investigated period were $21.4^{\circ} \mathrm{C}$ and $161.1 \mathrm{~mm}$, respectively (Figure 1).

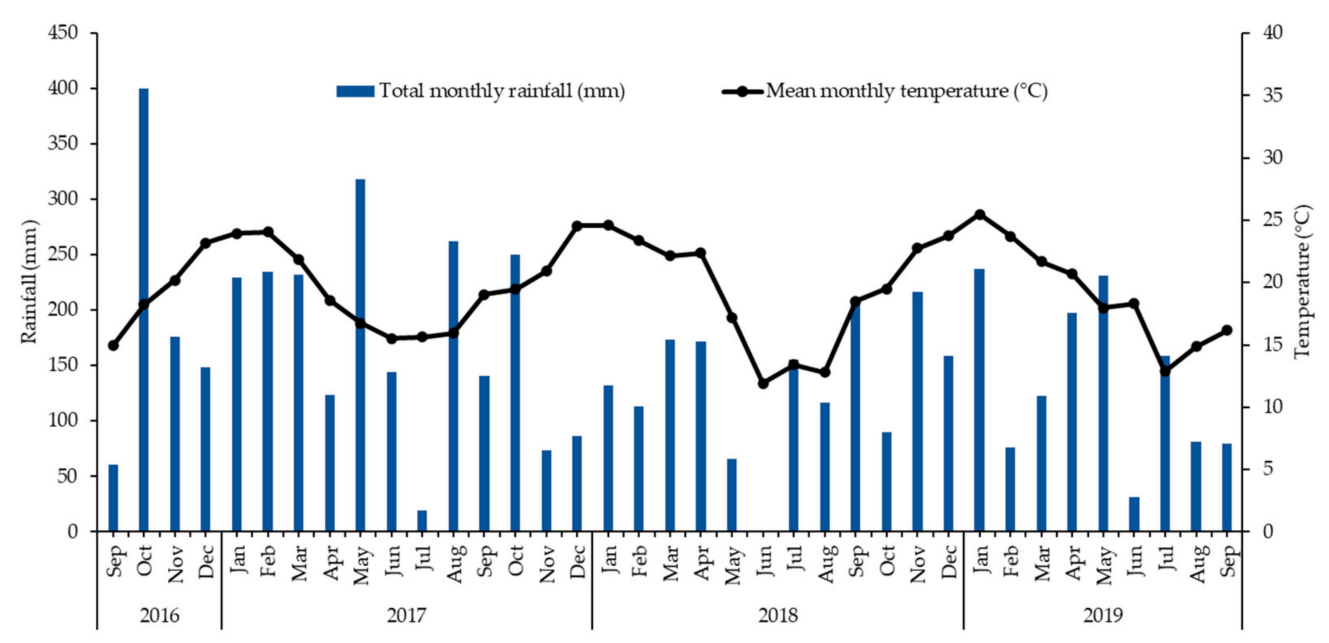

Figure 1. Total monthly rainfall $(\mathrm{mm})$ and mean monthly air temperature $\left({ }^{\circ} \mathrm{C}\right)$ throughout the study conducted with $H$. heptaphyllus plants in the field-data were provided by the weather station in Santa Maria County, Rio Grande do Sul State, Brazil. Source: [18]. 
Vegetation in the experimental site comprised species such as Desmodium incanum DC, Andropogon lateralis Nees, Axonopus affinis Chase, Aristida laevis (Nees) Kunth and Paspalum plicatulum Michx. Soil (Table 1) was classified as Typic Hapludalf [19].

Table 1. Physical and chemical soil characterization in the $0-0.2 \mathrm{~m}$ soil layer in the experimental site, before study installation.

\begin{tabular}{|c|c|}
\hline Soil Properties & Value \\
\hline Clay $^{\mathrm{a}}\left(\mathrm{g} \mathrm{kg}^{-1}\right)$ & 170 \\
\hline Silt ${ }^{\text {a }}\left(\mathrm{g} \mathrm{kg}^{-1}\right)$ & 130 \\
\hline Sand $^{\mathrm{a}}\left(\mathrm{g} \mathrm{kg}^{-1}\right)$ & 700 \\
\hline Organic matter ${ }^{\mathrm{b}}\left(\mathrm{g} \mathrm{kg}^{-1}\right)$ & 8.0 \\
\hline $\mathrm{pH}$ in water (1:1 ratio) & 6.0 \\
\hline Available $\mathrm{P}^{\mathrm{c}}\left(\mathrm{mg} \mathrm{kg}^{-1}\right)$ & 10.0 \\
\hline Exchangeable $\mathrm{K}^{\mathrm{c}}\left(\mathrm{mg} \mathrm{kg}^{-1}\right)$ & 48.0 \\
\hline Exchangeable $\mathrm{Ca}{ }^{\mathrm{d}}\left(\mathrm{cmol}_{\mathrm{C}} \mathrm{kg}^{-1}\right)$ & 1.2 \\
\hline Exchangeable $\mathrm{Mg}^{\mathrm{d}}\left(\mathrm{cmol}_{\mathrm{C}} \mathrm{kg}^{-1}\right)$ & 0.6 \\
\hline Exchangeable $\mathrm{Al}^{\mathrm{d}}\left(\mathrm{cmol}_{\mathrm{c}} \mathrm{kg}^{-1}\right)$ & 0.0 \\
\hline
\end{tabular}

Note: soil analysis were determined before soil disturbance at $0-0.2 \mathrm{~m}$ of depth. Values indicate the mean recorded for five replicates. ${ }^{\text {a }}$ Pipette method [20]; ${ }^{\mathrm{b}}$ Walkley-black method [21]; ${ }^{\mathrm{c}}$ Extracted by Mehlich-1 [21]; ${ }^{\mathrm{d}}$ Extracted by $\mathrm{KCl} 1 \mathrm{~mol} \mathrm{~L}^{-1}$ [21].

\subsection{Seed Collection and Seedling Production}

Seeds used to produce seedlings were collected from matrix trees grown in Deciduous Seasonal Forest fragments (latitude $29^{\circ} 79^{\prime} 38.1^{\prime \prime} \mathrm{S}$ and longitude $53^{\circ} 66^{\prime} 46.9^{\prime \prime} \mathrm{W}$ ) in Santa Maria County-RS. Collected seeds were extracted and processed in order to form seed lots.

Seeds were sown in containers (polypropylene tube-type; capacity of $180 \mathrm{~cm}^{3}$ ) filled with commercial substrate (Sphagnum peat and vermiculite) and carbonized rice husk (ratio of 2:1, v:v). Baseline fertilization comprised $9 \mathrm{~g} / \mathrm{L}$ of controlled-release fertilizer (N-P-K, 15-9-12) homogenized to the substrate before sowing. Tubes were placed on trays and allocated in the emergence and growth area and placed in an area under $50 \%$ light for four months. After this period was over, seedlings were transferred to the acclimation area for 30 days. Finally, seedlings presenting mean stem height and diameter of $0.315 \mathrm{~m}$ and $4.5 \mathrm{~mm}$, respectively, were used for transplanting.

\subsection{Silvicultural Practices and Experimental Design}

Weeding was conducted, three days before transplantation, in the experimental site with the application of non-selective systemic herbicide (Glyphosate-N (phosphonomethyl) glycine) at $4.5 \mathrm{~L} \mathrm{ha}^{-1}$, with the aid of sprayer (flow rate of $500 \mathrm{~L} \mathrm{ha}^{-1}$ ) coupled to a tractor. Holes $(0.15 \mathrm{~m}$ diameter $\times 0.2 \mathrm{~m}$ depth) were manually opened in the soil with the aid of articulated digger $(2 \mathrm{~m} \times 2 \mathrm{~m}$ spacing $)$, before transplant.

Transplanted seedlings were irrigated with approximately two liters of water per plant in order to avoid air pocket formation between the roots and the soil, as well as to keep the root system hydrated. In addition, all seedlings were fertilized with $90 \mathrm{~kg} \mathrm{~N} \mathrm{ha}^{-1}$ and $37 \mathrm{~kg}$ $\mathrm{K} \mathrm{ha}^{-1}$ of urea $(45 \% \mathrm{~N})$ and potassium chloride $(33 \% \mathrm{~K})$ fertilization sources, respectively.

A factorial completely randomized split-plot-in-time design was used in three blocks, with the main plot comprising $\mathrm{P}$ application ( 0 and $\left.40 \mathrm{~kg} \mathrm{P} \mathrm{ha}{ }^{-1}\right)$ and the subplot to sampling time (18 and 36 months after planting). Phosphorus rate was defined taking into consideration the doses recommended for Eucalyptus spp. culture [22] due to lack of specific recommendation for phosphate fertilizer application in $H$. heptaphyllus. Fertilizers were applied at the soil layer 0.1 to $0.15 \mathrm{~m}$ deep, in distant pits, approximately $0.15 \mathrm{~m}$ away from the seedlings.

Experiment maintenance was based on the control of leafcutter ants belonging to genera Atta and Acromyrmex by using granulated baits; weeds were controlled through manual weeding (crowning), mowing or chemical weeding, based on the application of 
4.5 $\mathrm{L} \mathrm{ha}^{-1}$ of non-selective systemic herbicide (Glyphosate- $\mathrm{N}$ (phosphonomethyl) glycine) with the aid of knapsack sprayer at flow rate of $350 \mathrm{~L}_{\text {syrup ha }}{ }^{-1}$.

\subsection{Soil and Leaf Collection and P Analysis}

In March 2018 and September 2019, fully expanded leaves of 4 samples per treatment were collected from the upper third of the plants, washed in distilled water and oven-dried in a forced ventilation at $65^{\circ} \mathrm{C}$ until constant weight. Leaf tissue was crushed in Willey mill, sieved in 20 mesh, subjected to sulfuric acid digestion [21] and analyzed for P.

Soil samples were collected with auger from the 0-0.2 m layer in March 2018 and September 2019. Eight subsamples were collected around plants $(\cong 0.25 \mathrm{~m})$ in each treatment. Soil samples were air-dried, sieved in $2 \mathrm{~mm}$ mesh and subjected to available $\mathrm{P}$ extraction (extracted by Mehlich-1) [21].

Phosphorus concentration in leaf tissue and soil samples was determined through colorimetry, based on the methodology proposed by Murphy and Riley [23], at wavelengths of $882 \mathrm{~nm}$, in UV-visible spectrophotometer (SF325NM, Bel Engineering, Monza, Italy).

\subsection{Plant Height and Root System Morphology}

Plant height was measured from the ground level up to the apical bud, with the aid of graduated ruler, in March 2018 and September 2019.

Acrylic tubes suitable for the minirhizotron technique were installed in September 2017 to evaluate the growth of the seedling root system of H. heptaphyllus plants. A hole was opened $0.5 \mathrm{~m}$ from the stem, at $45^{\circ}$ angle in relation to soil surface, on the seedling planting line. Holes used to allocate the tubes were performed with spiral drill $(70 \mathrm{~mm}$ in diameter and $1.5 \mathrm{~m}$ long) coupled to gasoline-powered soil drill (White, Bps 52). One transparent acrylic tube per plant (external diameter of $70 \mathrm{~mm}, 1.05 \mathrm{~m}$ in length, capable of reaching $0.80 \mathrm{~m}$ in depth) was inserted into the hole and used for future scans. The tubes were internally protected by non-toxic, lightweight and waterproof plastic polyethylene rod. Their bottom end was sealed with a plug to avoid water infiltration. The upper end of the tubes was covered with PVC pipes ( $100 \mathrm{~mm}$ in diameter) to minimize heat exchange and water vapor. An adhesive was added to the outer surface of each tube and used as an initial permanent reference position to scan all captured images. Four images along the tube at fixed dimensions of $0.216 \mathrm{~m} \times 0.196 \mathrm{~m}$, were captured.

\subsection{Image Collection and Analysis}

Scanning was performed 18 and 36 months after transplantation (MAT), after system stabilization (soil-plant-tube), and images were generated in situ by root system scanner (CI-600 Growth Monitoring System, CID Bio-Science, 1554 NE 3rd Avenue - Camas, WA, USA) at a resolution of $600 \mathrm{dpi}$ (Figure S1). Subsequently, images collected (TIFF format) in each repetition and soil layer $(0-0.2,0.2-0.4,0.4-0.6$ and $0.6-0.8 \mathrm{~m})$ were analyzed in RootSnap! ${ }^{\circledR}$ CI-690 computer software version 1.3.2.25 (CID Bio-Science), based on the manual drawing of each root. Next, total root length $\left(\mathrm{mm} \mathrm{plant}^{-1}\right)$, mean root diameter $(\mathrm{mm})$ and total root volume $\left(\mathrm{mm}^{3}\right.$ tube $\left.{ }^{-1}\right)$ in each soil layer were determined.

In each image obtained, the roots were classified into live roots and dead roots. The classification regarding survival was made visually and subjectively (Figure S2).

\subsection{Statistical Analysis}

The results were subjected to analysis of the assumptions of normality of residuals and homogeneity of variance by the Shapiro-Wilk and Bartlett test, respectively. Box-Cox was used to transform data that did not show normality and/or homogeneity of variance. Subsequently, the two-way analysis of variance $(p<0.05)$ was performed. After finding a difference between treatments (F-statistics), for the parameters $\mathrm{P}$ concentration in soil and leaves and plant height, the Tukey test $(p<0.05)$ was performed for the quantitative factor "P rate" and for qualitative factor "age". For root morphological parameters, whenever there was a difference between treatments, the Tukey test $(p<0.05)$ was used for the factors 
"P rate" and "soil layer". The "ExpDes.pt" package [24] available in the R Softwar [25] was used to analysis.

In addition to analysis of variance, multivariate principal component analysis (PCA) was performed by using the "Factoextra" [26] and "FactoMineR" [27] packages available in the R statistical environment [25]. Root morphological parameters in four different soil layers (length, diameter, volume), P concentration in leaves and soil, and plant height were used as response variables, whereas "P rate" and "time" were used as variation sources. PCA was performed based on a set of principal components (components 1 and 2 were used in the current study), which reflect a set of standardized orthogonal linear combinations that together explain the original data variability.

\section{Results}

\subsection{P in Soil and Leaves and Plant Height}

No significant interaction between $\mathrm{P}$ rate and plant age was observed for $\mathrm{P}$ concentration in the soil (Figure 2a,b) and leaves (Figure $3 a, b)$. The highest available $P$ in the $0-0.2 \mathrm{~m}$ soil layer was observed at 18 MAT (Figure 2a). In the control plots $(p=0)$, the concentration of $\mathrm{P}$ available in the soil was $2.3 \mathrm{mg} / \mathrm{kg}$, which was approximately 9 times lower than observed in soil fertilized with $40 \mathrm{~kg} \mathrm{P} \mathrm{ha}^{-1}$ (Figure 2b).

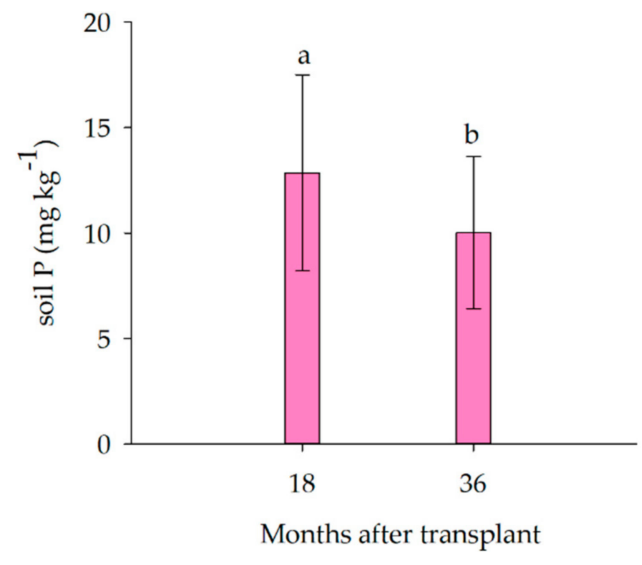

(a)

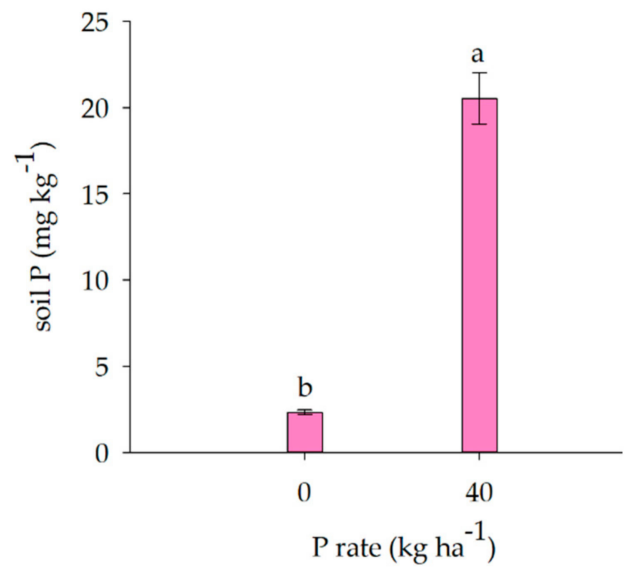

(b)

Figure 2. P concentration in the soil (a,b) of H. heptaphyllus plants (at 18 and $36 \mathrm{MAT}$ ) subjected to applications of 0 and $40 \mathrm{~kg} \mathrm{P} \mathrm{ha}^{-1}$. (a) depicts the adjusted bars with mean values at 18 and 36 months after transplant (MAT) compared based on Tukey's test $(p<0.05)$ without considering the P rate, since the interaction was not significant at $5 \%$ based on two-way analysis of variance. (b) depicts the adjusted bars with mean values of the P rate compared based on Tukey's test $(p<0.05)$ without considering time, since the interaction was not significant at $5 \%$ based on two-way analysis of variance. Vertical bars represent the standard error of three repetitions.

Phosphorus concentration in leaves was significantly higher at 18 MAT than at 36 MAT (Figure 3a), but it was not influenced by $\mathrm{P}$ supply (Figure 3b).

A significant interaction between $P$ rate and plant age was measured for height (Figure 4). Plant height was significantly higher as a consequence of $\mathrm{P}$ supply in comparison to control plants at both sampling days; in addition, at 36 MAT plant were higher than at 18 MAT (Figure 4).

A significant interaction between $P$ rate and soil layer was measured for root length at 18 MAT (Figure 5a) and 36 MAT (Figure 5b). At 18 MAT, the supply of P induced and increased total root length in comparison to control at all sampling depths, with the exception of $0.6-0.8 \mathrm{~m}$, where the two fertilization strategies induce similar values (Figure 5a); root value decreased with depth (Figure 5a). 
At 18 MAT (Figure 5b), the trend was similar to that observed at 36 MAT with a higher root length as a consequence of $\mathrm{P}$ supply in comparison to control in the shallowest soil layer; in the deeper soil layer $(0.4-0.8 \mathrm{~m})$, the two fertilization strategies induced a similar root length (Figure 5). Total root length decreased with depth (Figure 5).

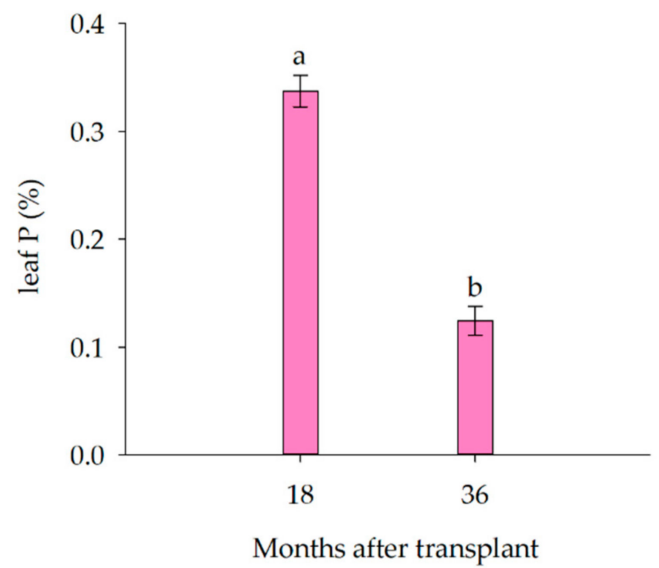

(a)

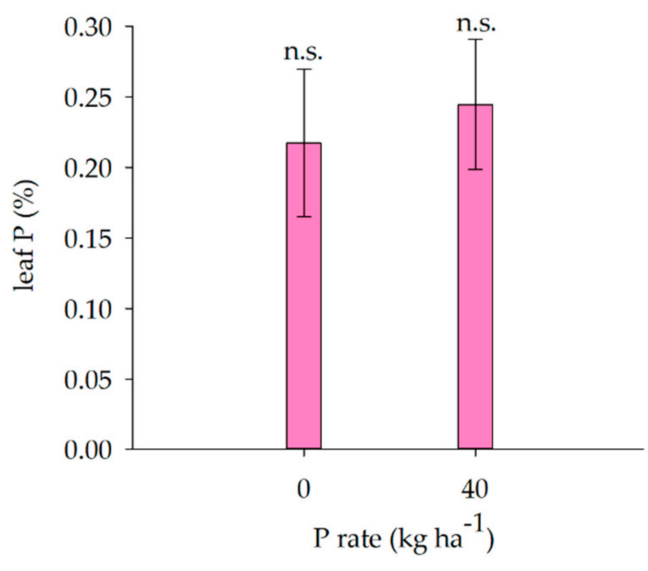

(b)

Figure 3. $\mathrm{P}$ concentration in leaves $(\mathbf{a}, \mathbf{b})$ of $H$. heptaphyllus plants (at 18 and $36 \mathrm{MAT}$ ) subjected to applications of 0 and $40 \mathrm{~kg} \mathrm{P} \mathrm{ha}^{-1}$. (a) depicts the adjusted bars with mean values at 18 and 36 months after transplant (MAT) compared based on Tukey's test $(p<0.05)$ without considering the P rate, since the interaction was not significant at $5 \%$ based on two-way analysis of variance. (b) depicts the adjusted bars with mean values of the $P$ rate without considering time since the interaction was not significant in alpha 5\% based on two-way analysis of variance. Vertical bars represent the standard error of three repetitions. n.s. $=\mathrm{F}$ not significant at $5 \%$ probability.

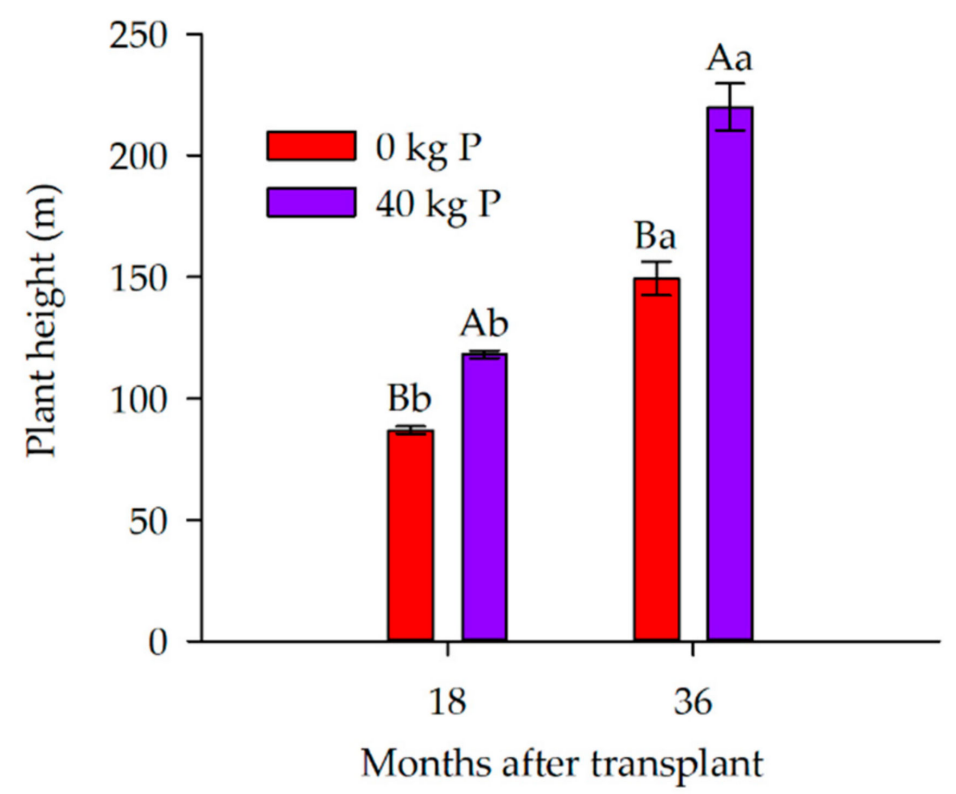

Figure 4. Height of $H$. heptaphyllus plants (at 18 and 36 months after transplant) subjected to applications of 0 and $40 \mathrm{~kg} \mathrm{P} \mathrm{ha}^{-1}$. Uppercase letters compare $\mathrm{P}$ rate considering the same time, while lowercase letters compare times based on the Tukey test $(p<0.05)$, since the interaction was significant at $5 \%$ based on two-way analysis of variance. Vertical bars represent the standard error of three repetitions. 


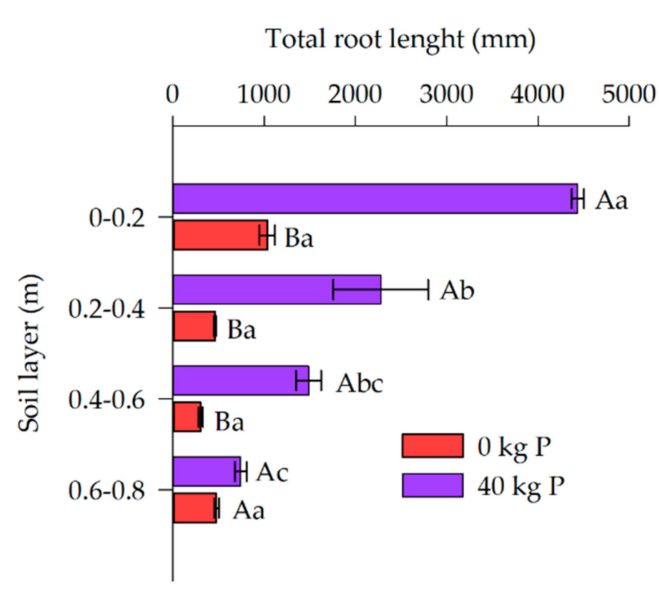

(a)

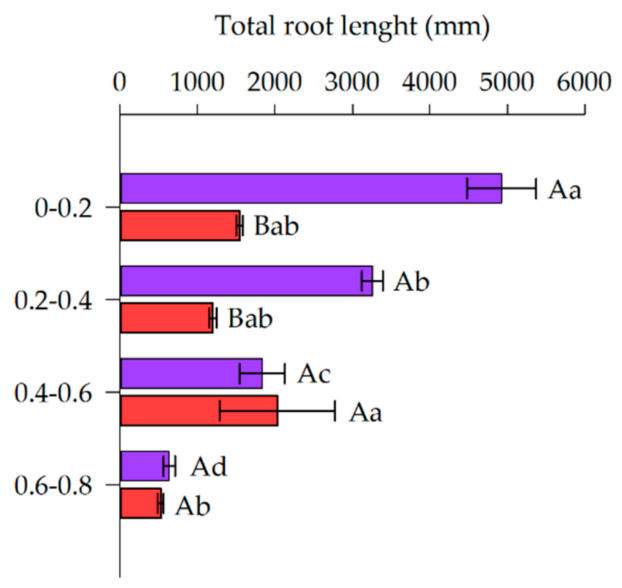

(b)

Figure 5. Total length of living roots $(\mathrm{mm})$ in $0-0.2,0.2-0.4,0.4-0.6$ and $0.6-0.8 \mathrm{~m}$ soil layers at 18 (a) and 36 months after transplant (b) in H. heptaphyllus plants subjected to applications of 0 and $40 \mathrm{~kg} \mathrm{P} \mathrm{ha}^{-1}$. (a,b) The uppercase letters compare P rate considering the same soil layer, while lowercase letters compare soil layers based on the Tukey test $(p<0.05)$, since the interaction was significant at $5 \%$ based on two-way analysis of variance. Horizontal bars represent the standard error of three repetitions.

\subsection{Mean Diameter of Living Roots}

A significant interaction between $P$ rate and soil layer was measured for root diameter at 18 MAT (Figure 6a). At $18 \mathrm{MAT}$, the highest diameter value was recorded in the $0.4-0.6 \mathrm{~m}$ layer, in plants grown in soil subjected to application of $40 \mathrm{~kg} \mathrm{P} \mathrm{ha}^{-1}$ (Figure 6a), followed by values in the $0.6-0.8 \mathrm{~m}$ layer, no matter the fertilization; on the other hand, the lowest values were measured in the $0.2-0.4 \mathrm{~m}$ soil layer, followed by the $0-0.2 \mathrm{~m}$ layer, with no differences between fertilized and not fertilized plants (Figure 6a).

No significant interaction between $P$ rate and soil layer was measured for root diameter at 36 MAT (Figure 6b,c). At 36 MAT, the diameter measured in the deepest soil layer was higher than that measured in the shallowest layers $(0-0.4 \mathrm{~m})$; values recorded at $0.4-0.6 \mathrm{~m}$ soil depth were higher than those at $0.2-0.4 \mathrm{~m}$ and similar to $0-0.2 \mathrm{~m}$ and $0.6-0.8 \mathrm{~m}$ (Figure $6 \mathrm{~b}$ ). The supply of $\mathrm{P}$ induced an increase in roots diameter in comparison to control (Figure 6c).

\subsection{Total Volume of Living Roots}

A significant interaction between $P$ rate and soil layer was measured for root volume in $18 \mathrm{MAT}$ (Figure 7a) and $36 \mathrm{MAT}$ (Figure 7b). At $18 \mathrm{MAT}$, the supply of $\mathrm{P}$ at $40 \mathrm{~kg} \mathrm{P} \mathrm{ha}^{-1}$ induced an increase in volume of living roots at all depths except the deepest one, where the two fertilization treatments were similar (Figure 7a); a similar trend was also observed at 36 MAT (Figure 7b).

\subsection{Principal Component Analysis (PCA)}

Principal component analysis (PCA) was performed by extracting the first two components (PC1 and PC2), which together explained $72.3 \%$ of the original data variability (Figure 8). PC1 has explained 53\% of data variability; it had a stronger influence than PC2 on root length in layers $0-0.2 \mathrm{~m}$ and $0.2-0.4 \mathrm{~m}$, on root diameter in layer $0.4-0.6 \mathrm{~m}$, on root volume in layers $0-0.2 \mathrm{~m}, 0.4-0.6 \mathrm{~m}$ and $0.6-0.8 \mathrm{~m}$, and on P concentration in the soil. PC1 was effective in separating treatments into two large groups. The group to the right of the PC1 axis comprised plants subjected to application of $40 \mathrm{~kg} \mathrm{P} \mathrm{ha}^{-1}$ (circles), which differed from plants subjected to application of $0 \mathrm{~kg} \mathrm{P} \mathrm{ha}^{-1}$ (triangles) and were placed to the left of the PC1 distribution. PC2 has explained 19.3\% of data variation; P concentration in leaves was the response variable that mostly influenced this variation. PC2 was effective 
in separating individuals based on assessment time. Observations performed at 18 MAT (red) were positioned above the PC2 axis; they diverged from observations performed at 36 MAT (green), which were positioned below the PC2 axis. Plants subjected to application of $40 \mathrm{~kg} \mathrm{P} \mathrm{ha}^{-1}$ and evaluated at 36 MAT were the ones showing the highest height values, which presented a positive correlation to root morphological variables such as root length (RL) and volume (RV) in soil layer $0.2-0.4 \mathrm{~m}$. Phosphorus content available in the soil was positively correlated to root volume in soil layer $0.4-0.6 \mathrm{~m}$ (Figure 8).

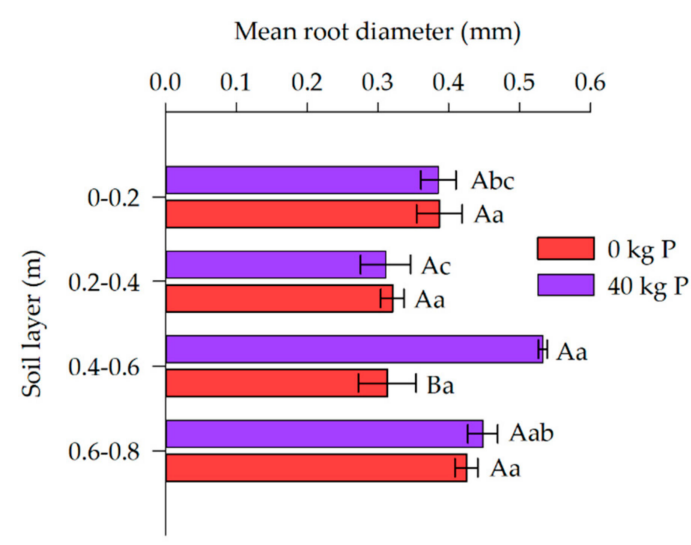

(a)

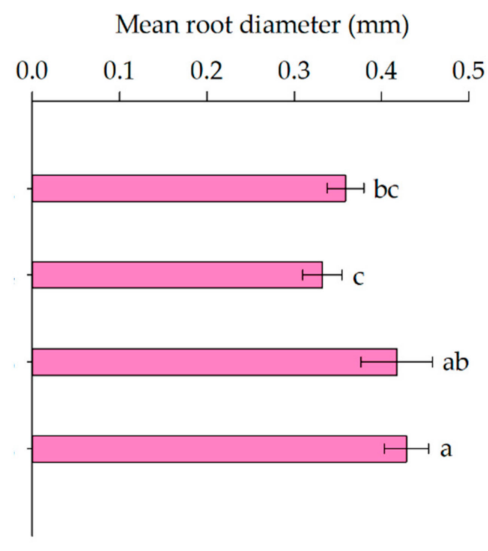

(b)

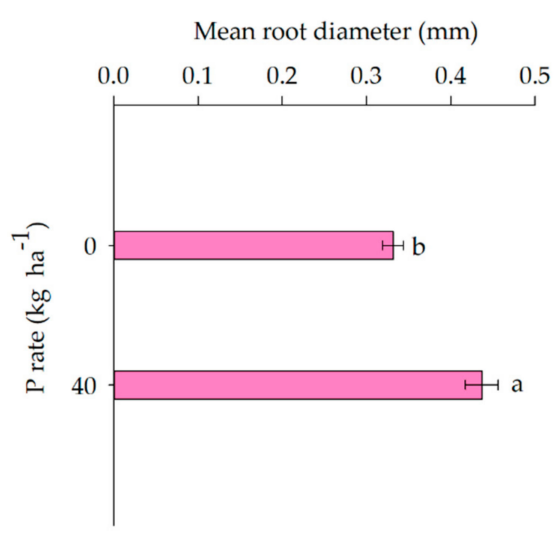

(c)

Figure 6. Mean diameter of living roots $(\mathrm{mm})$ of $H$. heptaphyllus plants subjected to applications of 0 and $40 \mathrm{~kg} \mathrm{P} \mathrm{ha}^{-1}$ as observed in $0-0.2 \mathrm{~m}, 0.2-0.4 \mathrm{~m}, 0.4-0.6 \mathrm{~m}$ and $0.6-0.8 \mathrm{~m}$ soil layers at 18 (a) and 36 months after transplant (MAT) (b,c). (a) The uppercase letters compare P rate considering the same soil layer, while lowercase letters compare soil layers based on the Tukey test $(p<0.05)$, since the interaction was significant at $5 \%$ based on two-way analysis of variance. (b) depicts the adjusted bars with mean values at soil layers at 36 MAT compared based on Tukey's test $(p<0.05)$ without considering the P rate, since the interaction was not significant at $5 \%$ based on two-way analysis of variance. (c) depicts the adjusted bars with mean values of the P rate at 36 MAT compared based on Tukey's test $(p<0.05)$ without considering soil layers, since the interaction was not significant at $5 \%$ based on two-way analysis of variance. Horizontal bars represent the standard error of three repetitions. 


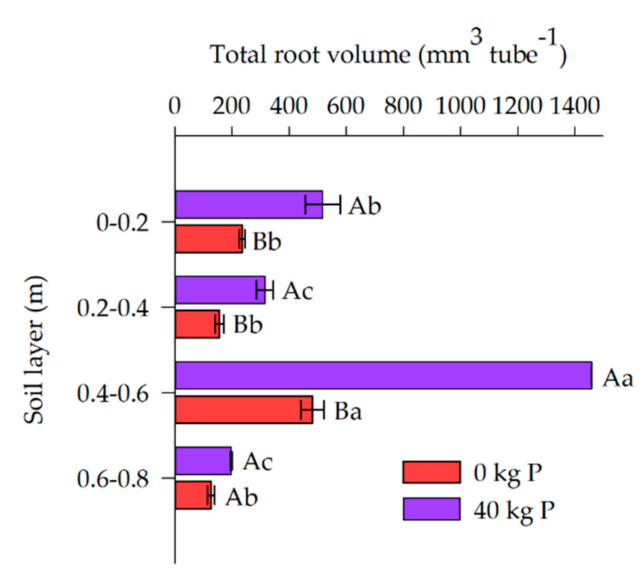

(a)

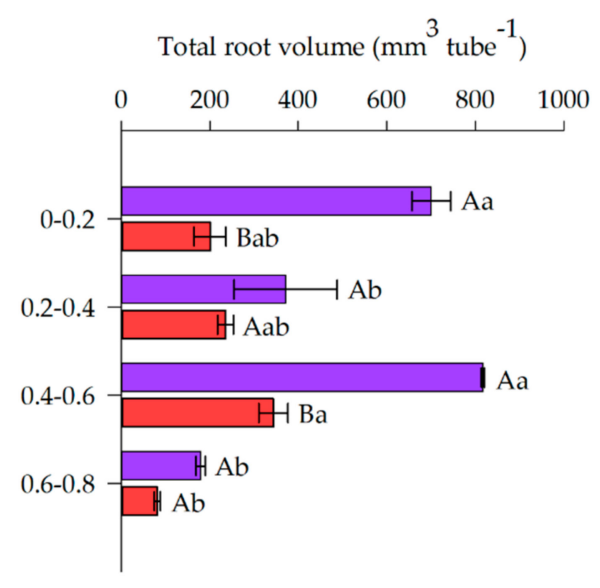

(b)

Figure 7. Total living root volume $\left(\mathrm{mm}^{3}\right.$ tube $\left.{ }^{-1}\right)$ in $H$. heptaphyllus plants subjected to applications of 0 and $40 \mathrm{~kg} \mathrm{P} \mathrm{ha}^{-1}$ as observed in 0-0.2 m, 0.2-0.4 m, 0.4-0.6 m and 0.6-0.8 $\mathrm{m}$ layers at 18 (a) and 36 months after transplant $(\mathbf{b})$. (a,b) The uppercase letters compare $P$ rate considering the same soil layer, while lowercase letters compare soil layers based on the Tukey test $(p<0.05)$, since the interaction was significant at $5 \%$ based on two-way analysis of variance (ANOVA). Horizontal bars represent the standard error of three repetitions.

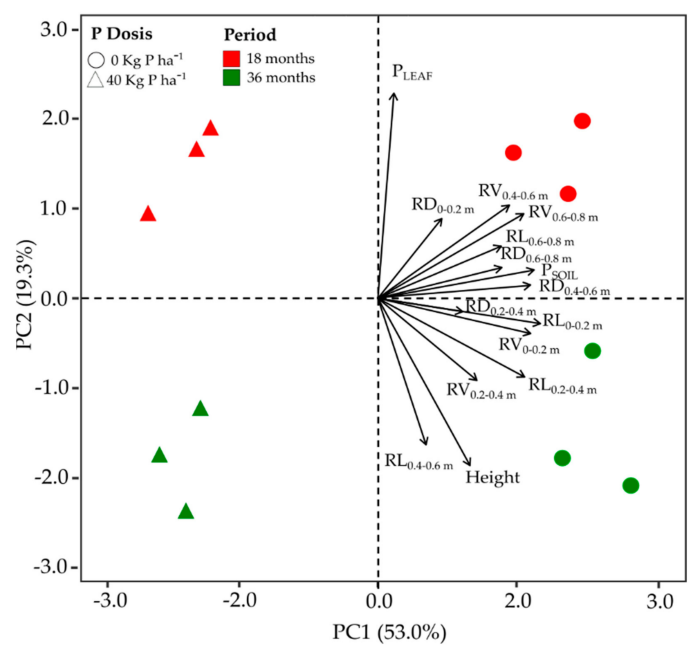

Figure 8. Correlation between principal components 1 (PC1) and 2 (PC2) in root morphological variables, $\mathrm{P}$ concentration in soil and leaves, and height of $H$. heptaphyllus plants subjected to application of different $\mathrm{P}$ rate in the soil and evaluated at different times, where $\mathrm{P}_{\mathrm{LEAF}}$ : phosphorus concentration in leaves; $\mathrm{P}_{\mathrm{SOIL}}$ : phosphorus content in the soil; $\mathrm{RD}_{0-0.2 \mathrm{~m}}$ : total living root volume $\left(\mathrm{mm}^{3}\right.$ tube $\left.{ }^{-1}\right)$ in $0-0.2 \mathrm{~m}$ soil layers; $\mathrm{RD}_{0.2-0.4 \mathrm{~m}}$ : total living root volume $\left(\mathrm{mm}^{3}\right.$ tube $\left.{ }^{-1}\right)$ in $0.2-0.4$ soil layers; $\mathrm{RD}_{0.4-0.6 \mathrm{~m}}$ : total living root volume $\left(\mathrm{mm}^{3}\right.$ tube $\left.{ }^{-1}\right)$ in $0.4-0.6$ soil layers; $\mathrm{RD}_{0.6-0.8 \mathrm{~m}}$ : total living root volume $\left(\mathrm{mm}^{3}\right.$ tube $\left.{ }^{-1}\right)$ in $0.6-0.8 \mathrm{~m}$ soil layers; $\mathrm{RL}_{0-0.2 \mathrm{~m}}$ : total length of living roots $(\mathrm{mm})$ in $0-0.2 \mathrm{~m}$ soil layers; $\mathrm{RL}_{0.2-04 \mathrm{~m}}$ : total length of living roots $(\mathrm{mm})$ in $0.2-0.4$ soil layers; $\mathrm{RL}_{0.4-0.6 \mathrm{~m}}$ : total length of living roots $(\mathrm{mm})$ in $0.4-0.6$ soil layers; $\mathrm{RL}_{0.6-0.8 \mathrm{~m}}$ :total length of living roots $(\mathrm{mm})$ in 0.6-0.8 m soil layers; $\mathrm{RV}_{0-0.2 \mathrm{~m}}$ : total living root volume $\left(\mathrm{mm}^{3}\right.$ tube $\left.{ }^{-1}\right)$ in $0-0.2 \mathrm{~m}$ soil layer; $\mathrm{RV}_{0.2-04 \mathrm{~m}}$ : total living root volume $\left(\mathrm{mm}^{3}\right.$ tube $\left.{ }^{-1}\right)$ in $0.2-0.4 \mathrm{~m}$ soil layer; $\mathrm{RV}_{0.4-0.6 \mathrm{~m}}$ : total living root volume $\left(\mathrm{mm}^{3}\right.$ tube $\left.{ }^{-1}\right)$ in $0-0.2 \mathrm{~m}$ soil layer; $\mathrm{RV}_{0.6-0.8 \mathrm{~m}}$ : total living root volume $\left(\mathrm{mm}^{3}\right.$ tube $\left.^{-1}\right)$ in $0-0.2 \mathrm{~m}$ soil layer.

\section{Discussion}

Phosphorous fertilization did not change plant height in the first 18 MAT. This outcome may be associated with lower root system development at the initial root growth stage, as well as the low mobility of $P$ in the soil $[28,29]$, because of the affinity of phosphate 
ion adsorption to functional groups of reactive soil particles, such as oxides, oxyhydroxides and clay minerals $[15,29,30]$. However, an increase in plant height was recorded as a consequence of $\mathrm{P}$ addition at $36 \mathrm{MAT}$. This increase in plant growth could be the consequence of an increase in P uptake that happened thanks to the enhancement of root length and volume, stimulated by P fertilization. Increased P absorption by roots also [31] stimulated ATP biosynthesis and assured higher photosynthetic rates, which contributed to the cell division and expansion in the shoot [28,31,32]. The consequence of this metabolic process is the increase in plant height [12]. Some research with plants of arboreal species cultivated with $P$ increment showed a similar effect in growth [12,28].

Soil P application significantly modified roots and plant growth in $H$. heptaphyllus, probably because of a better $\mathrm{P}$ availability in soil. Indeed, phosphorous fertilizer was applied close to the plants and probably, the $\mathrm{P}$ forms like $\mathrm{H}_{2} \mathrm{PO}_{4}{ }^{-}$e $\mathrm{HPO}_{4}{ }^{2-}$ got close to the external surface of roots, mainly by diffusion, enhancing the absorption of $\mathrm{P}$ from the soil solution $[33,34]$. Thus, the longer root length observed in the $0-0.2 \mathrm{~m}$ soil layer, close to the zone enriched with $\mathrm{P}$, enhanced the establishment and growth in height of plants $[12,28]$, as observed by the positive correlation among variables, such as root length, diameter and volume, with plant height in the PCA.

In general, the higher values of total root volume can also be explained by the increase in $\mathrm{P}$ derived from fertilizer application. Thus, fertilization stimulated the emission of roots that were observed in the $0-0.2 \mathrm{~m}$ layer. On the other hand, the largest total volume of roots observed in the $0.4-0.6 \mathrm{~m}$ layer probably occurred due to the migration of $\mathrm{P}$ in the profile, which is possible due to the sandy soil and low P adsorption capacity [12]. This volume growth in depth can also be associated with lignified roots, which are responsible for supporting plants [33,35].

The low P availability in unfertilized soil induced a stunted growth in plants and a lower development of the root system. Native $\mathrm{P}$ in the soil is strongly adsorbed to functional groups of reactive soil particles, such as oxides, oxyhydroxides and clay minerals, which leads to lower mobility in the soil and, consequently, decreased P availability for plant absorption [29-31], which is reflected in lower aerial and root growth. Plants under P deficiency usually show suppression in principal root growth, associated with increased lateral roots and cluster roots, due to decreased levels of gibberellic acid caused by lack of $\mathrm{Pi}[7,8,36,37]$. In addition, it is known that to deal with low $\mathrm{P}$ availability, plants can develop $\mathrm{P}$ acquisition strategies such as root morphological modifications to increase soil exploration (e.g., cluster roots) and exudation of organic acids, including carboxylates, phosphatases and proteases, among other adaptations at the morphological and biochemical level $[7,8,36]$. However, this often occurs at the expense of growth and photosynthesis [38], causing lower biomass production.

Reduced P availability in the soil from 18 to 36 MAT was probably caused by P uptake in plants [39-41]. ] In addition, reduced P availability observed over time may be part of the $\mathrm{P}$ deriving from fertilizer forms, an inner sphere complex with functional groups of inorganic particles, and it reduces the $\mathrm{P}$ amounts extracted with the aid of simple extractors, such as Mehlich-1 [30,42,43].

The higher $\mathrm{P}$ concentration observed in leaves at $18 \mathrm{MAT}$ and the strong correlation between these variables in PCA could be due to the small young plants with a limited leaf area that led to increased $\mathrm{P}$ concentration in leaf tissue. However, it is also likely that there was a redistribution of $\mathrm{P}$ from the leaves to other growing organs, which can be confirmed by the reduced values of P observed in the leaves at 36 MAT. However, part of the $P$ available in leaves could be remobilized and redistributed to perennial reserve organs, mainly to branches and roots, reducing plant dependence on $\mathrm{P}$ deriving from the soil; this phenomenon was previously observed in native trees subjected to $\mathrm{P}$ application [44-46]. 


\section{Conclusions}

Phosphorus application has increased P concentration the soil, stimulated increase in root length and volume of $H$. heptaphyllus plants, mainly in the superficial soil layer $(0-0.2 \mathrm{~m}), 18$ and 36 months after seedling transplantation, leading to higher plant growth.

In conclusion, we can assess that $\mathrm{P}$ application at the rate of $40 \mathrm{~kg} \mathrm{P}^{-1}$ can contribute to faster growth of $H$. heptaphyllus plants; further study should be conducted to evaluate the correct $P$ rate to apply and if splitting the doses or applying it yearly could be an effective strategy for $H$. heptaphyllus plants cultivation.

Supplementary Materials: The following are available online at https:/ /www.mdpi.com/article/10 .3390 /agronomy11081563/s1, Figure S1: Images generated in situ by a root system scanner (CI-600 Growth Monitoring System, CID, USA) with 600 dpi resolution, with an image of the root system 18 months after transplantation (MAT), soil layer 0-0.2 m, submitted to applications of 0 (a) and $40 \mathrm{~kg}$ P ha-1 (b), and image of the root system 36 months after transplantation (MAT) submitted to applications of 0 (c) and $40 \mathrm{~kg}$ P ha-1 (d), Figure S2: Image generated in situ by a root system scanner (CI-600 Growth Monitoring System, CID, USA) with 600 dpi resolution, which exemplifies the difference between root survival. Green arrows show examples of live roots and red arrows show examples of dead roots. Table S1: Database that supported this research.

Author Contributions: C.F.P.: Conceptualization, Methodology, Formal analysis, Writing-original draft, Writing-review and editing, Supervision, Visualization, Project administration. Á.L.P.B.: Conceptualization, Formal analysis, Writing—review and editing. C.F.P., Á.L.P.B., M.M.A., L.O.S., M.S.d.S.K., M.T., E.B. and G.B.: Methodology, Investigation. G.A.S.: Methodology, Resources. V.M.S., V.V.T.d.O., V.W.A. and L.O.S.: Resources, Writing-review and editing. M.M.A. and G.B.: Conceptualization, Methodology, Formal analysis, Writing-review and editing, Supervision, Project administration, Funding acquisition. All authors have read and agreed to the published version of the manuscript.

Funding: This research was funded by the National Council for Scientific and Technological Development (CNPq), grant number 309142/2018-0 and by the Coordination for the Improvement of Higher Education Personnel (CAPES), grant number 88882.427792/2019-01.

Institutional Review Board Statement: Not applicable.

Informed Consent Statement: Not applicable.

Data Availability Statement: The data presented in this study are available in Supplementary Material Table S1.

Acknowledgments: The authors are grateful to the Council for Scientific and Technological Development (CNPq) and Coordination for the Improvement of Higher Education Personnel (CAPES) for funding and grants awarded.

Conflicts of Interest: The authors declare no conflict of interest.

\section{References}

1. Berghetti, Á.L.P.; Araujo, M.M.; Tabaldi, L.A.; Turchetto, F.; Tassinari, A.; Bernardy, D.; Griebeler, A.M.; Barbosa, F.M.; Aimi, S.C.; Brunetto, G. Effects of Nitrogen Fertilization on the Growth and on Photochemical Efficiency in Plants of Handroanthus heptaphyllus. J. Plant Nutr. 2021, 44, 1-12. [CrossRef]

2. Mezzomo, J.C.; Araujo, M.M.; Turchetto, F.; Rorato, D.G.; Griebeler, A.M.; Berghetti, Á.L.P.; Barbosa, F.M. Silvicultural Potential of Handroanthus Heptaphyllus Under Doses of Controlled Release Fertilizer and Container Volume, in Nursery and in the Field. J. Agric. Sci. 2018, 10, 389-400. [CrossRef]

3. Mori, N.T.; Moraes, M.L.T.; de Morita, C.M.; Mori, E.S. Genetic Diversity between and within Populations of Handroanthus Heptaphyllus (Vell.) Mattos Using Microsatellite Markers. Cerne 2012, 18, 9-15. [CrossRef]

4. Scarante, A.G.; Da, M.D.F.; Matos, S.; Soares, M.T.S.; de Aguiar, A.V.; Wrege, M.S. Article Distribution of Handroanthus Heptaphyllus In Brazil and Future Projections According to Global Climate Change. Rev. Geama 2017, 3, $201-207$.

5. Borges, V.P.; Costa, M.A.P.D.C.; Ribas, R.F. Emergência e Crescimento Inicial de Tabebuia Heptaphylla (Vell.) Toledo Em Ambientes Contrastantes de Luz. Rev. Árvore 2014, 38, 523-531. [CrossRef]

6. Coradin, L.; Siminski, A.; Reis, A.; Ministério do Meio Ambiente. Espécies Nativas Da Flora Brasileira de Valor Econômico Atual Ou Potencial: Plantas Para o Futuro—Região Sul; Ministério do Meio Ambiente: Brasília, Brazil, 2011; ISBN 9788577381531. 
7. Ham, B.-K.; Chen, J.; Yan, Y.; Lucas, W.J. Insights into Plant Phosphate Sensing and Signaling. Curr. Opin. Biotechnol. 2018, 49, 1-9. [CrossRef]

8. Delgado, M.; Henríquez-Castillo, C.; Zuñiga-Feest, A.; Sepúlveda, F.; Hasbún, R.; Hanna, P.; Reyes-Díaz, M.; Bertin-Benavides, A. Cluster Roots of Embothrium Coccineum Modify Their Metabolism and Show Differential Gene Expression in Response to Phosphorus Supply. Plant Physiol. Biochem. 2021, 161, 191-199. [CrossRef] [PubMed]

9. Zavišić, A.; Polle, A. Dynamics of Phosphorus Nutrition, Allocation and Growth of Young Beech (Fagus Sylvatica L.) Trees in P-Rich and P-Poor Forest Soil. Tree Physiol. 2018, 38, 37-51. [CrossRef]

10. Swamy, H.K.M.; Anila, M.; Kale, R.R.; Bhadana, V.P.; Anantha, M.S.; Brajendra, P.; Hajira, S.K.; Balachiranjeevi, C.H.; Prasanna, B.L.; Pranathi, K.; et al. Phenotypic and Molecular Characterization of Rice Germplasm Lines and Identification of Novel Source for Low Soil Phosphorus Tolerance in Rice. Euphytica 2019, 215, 1-15. [CrossRef]

11. Mohidin, H.; Hanafi, M.M.; Rafii, Y.M.; Abdullah, S.N.A.; Idris, A.S.; Man, S.; Idris, J.; Sahebi, M. Determination of Optimum Levels of Nitrogen, Phosphorus and Potassium of Oil Palm Seedlings in Solution Culture. Bragantia 2015, 74, 247-254. [CrossRef]

12. Berghetti, Á.L.P.; Araujo, M.M.; Tabaldi, L.A.; Turchetto, F.; Aimi, S.C.; Rorato, D.G.; Marchezan, C.; Griebeler, A.M.; Barbosa, F.M.; Brunetto, G. Morphological, Physiological and Biochemical Traits of Cordia Trichotoma under Phosphorous Application and a Water-Retaining Polymer. J. For. Res. 2020, 32, 855-865. [CrossRef]

13. Heydari, M.M.; Brook, R.M.; Jones, D.L. The Role of Phosphorus Sources on Root Diameter, Root Length and Root Dry Matter of Barley (Hordeum vulgare L.). J. Plant Nutr. 2019, 42, 1-15. [CrossRef]

14. Gatiboni, L.C.; Schmitt, D.E.; Tiecher, T.; Veloso, M.G.; dos Santos, D.R.; Kaminski, J.; Brunetto, G. Plant Uptake of Legacy Phosphorus from Soils without P Fertilization. Nutr. Cycl. Agroecosyst. 2021, 119, 139-151. [CrossRef]

15. Brunetto, G.; Nava, G.; Ambrosini, V.G.; Comin, J.J.; Kaminski, J. The Pear Tree Response to Phosphorus and Potassium Fertilization. Rev. Bras. Frutic. 2015, 37, 507-516. [CrossRef]

16. Gerke, J. The Acquisition of Phosphate by Higher Plants: Effect of Carboxylate Release by the Roots. A Critical Review. J. Plant Nutr. Soil Sci. 2015, 178, 351-364. [CrossRef]

17. Alvares, C.A.; Stape, J.L.; Sentelhas, P.C.; de Moraes Gonçalves, J.L.; Sparovek, G. Köppen's Climate Classification Map for Brazil. Meteorol. Z. 2013, 22, 711-728. [CrossRef]

18. Bdmet-Inmet Banco de Dados Meteorológicos Para Ensino e Pesquisa; Instituto Nacional de Meteorologia. Temperaturas Máximas e Mínimas e Umidade Relativa Do Ar Anos 2016/2019. Available online: http:/ /www.Inmet.Gov.Br/Portal/ (accessed on 12 January 2021).

19. Soil Survey Staff. Keys to Soil Taxonomy, 12th ed.; Natural Resources Conservation Service, United States Department of Agriculture: Washington, DC, USA, 2014.

20. EMBRAPA-Centro Nacional de Pesquisa de Solos. Metodos Embrapa Analise Solo, 2nd ed.; EMBRAPA-CNPS: Rio de Janeiro, Brazil, 1997; ISBN 8585864036.

21. Tedesco, M.J.; Gianello, C.; Bissani, C.A.; Bohnen, H.; Volkweiss, S.J. Análise de Solo, Plantas e Outros Materiais; Universidade Federal do Rio Grande do Sul: Porto Alegre, Brazil, 1995.

22. CQFS-RS/SC. Manual de Calagem e Adubação Para Os Estados Do Rio Grande so Sul e Santa Catarina, 11th ed.; Sociedade Brasileira de Ciência do Solo/Núcleo Regional Sul: Frederico Westphalen, Brazil, 2016; Volume 11, ISBN 978-85-66301-80-9.

23. Murphy, J.; Riley, J.P. A Modified Single Solution Method for the Determination of Phosphate in Natural Waters. Anal. Chim. Acta 1962, 27, 31-36. [CrossRef]

24. Ferreira, E.B.; Cavalcanti, P.P.; Nogueira, D.A. ExpDes: An R Package for ANOVA and Experimental Designs. Appl. Math. 2014, 5, 2952-2958. [CrossRef]

25. R Core Team. R: A Language and Environment for Statistical Computing; R Core Team: Vienna, Austria, 2021.

26. Kassambara, A.; Mundt, F. Factoextra: Extract and Visualize the Results of Multivariate Data Analyses. R Package Version 2017, 1 , 337-354.

27. Lê, S.; Josse, J.; Husson, F. FactoMineR: An R Package for Multivariate Analysis. J. Stat. Softw. 2008, 25, 1-18. [CrossRef]

28. Crous, K.Y.; Ósvaldsson, A.; Ellsworth, D.S. Is Phosphorus Limiting in a Mature Eucalyptus Woodland? Phosphorus Fertilisation Stimulates Stem Growth. Plant Soil 2015, 391, 293-305. [CrossRef]

29. Fink, J.R.; Inda, A.V.; Bavaresco, J.; Barrón, V.; Torrent, J.; Bayer, C. Adsorption and Desorption of Phosphorus in Subtropical Soils as Affected by Management System and Mineralogy. Soil Tillage Res. 2016, 155, 62-68. [CrossRef]

30. De Freitas, E.C.S.; de Paiva, H.N.; Leite, H.G.; de Oliveira Neto, S.N. Effect of Phosphate Fertilization and Base Saturation of Substrate on the Seedlings Growth and Quality of Plathymenia Foliolosa Benth. Rev. Árvore 2017, 41. [CrossRef]

31. Noack, S.R.; McLaughlin, M.J.; Smernik, R.J.; McBeath, T.M.; Armstrong, R.D. Phosphorus Speciation in Mature Wheat and Canola Plants as Affected by Phosphorus Supply. Plant Soil 2014, 378, 125-137. [CrossRef]

32. Zambrosi, F.C.B.; Mattos, D.; Boaretto, R.M.; Quaggio, J.A.; Muraoka, T.; Syvertsen, J.P. Contribution of Phosphorus (32P) Absorption and Remobilization for Citrus Growth. Plant Soil 2012, 355, 353-362. [CrossRef]

33. Araújo, L.F.D.; Lima, R.E.; da Costa, L.D.O.; Silveira, Ê.M.D.C.; Bezerra, M.A. Alocação de Íons e Crescimento de Plantas de Cajueiro Anão-Precoce Irrigadas Com Água Salina No Campo. Rev. Bras. Eng. Agrícola Ambient. 2014, 18, S34-S38. [CrossRef]

34. Hairiah, K.; Widianto, W.; Suprayogo, D.; van Noordwijk, M. Tree Roots Anchoring and Binding Soil: Reducing Landslide Risk in Indonesian Agroforestry. Land 2020, 9, 256. [CrossRef] 
35. Freitas, T.A.S.; de Barroso, D.G.; Carneiro, J.G.D.A. Dinâmica de Raízes de Espécies Arbóreas: Visão Da Literatura. Ciênc. Florest. 2008, 18, 133-142. [CrossRef]

36. Aslam, M.M.; Karanja, J.K.; Yuan, W.; Zhang, Q.; Zhang, J.; Xu, W. Phosphorus Uptake Is Associated with the Rhizosheath Formation of Mature Cluster Roots in White Lupin under Soil Drying and Phosphorus Deficiency. Plant Physiol. Biochem. 2021, 166, 531-539. [CrossRef]

37. Jiang, C.; Gao, X.; Liao, L.; Harberd, N.P.; Fu, X. Phosphate Starvation Root Architecture and Anthocyanin Accumulation Responses Are Modulated by the Gibberellin-DELLA Signaling Pathway in Arabidopsis. Plant Physiol. 2007, 145, 1460-1470. [CrossRef] [PubMed]

38. Thuynsma, R.; Valentine, A.; Kleinert, A. Phosphorus Deficiency Affects the Allocation of Below-Ground Resources to Combined Cluster Roots and Nodules in Lupinus Albus. J. Plant Physiol. 2014, 171, 285-291. [CrossRef]

39. De Souza Magalhães, C.A.; Morales, M.M.; Rezende, F.A.; Langer, J. Eficiência de Fertilizantes Organominerais Fosfatados Em Mudas de Eucalipto. Sci. Agrar. 2017, 18, 80-85. [CrossRef]

40. Fantasma, L.P.R.D.; Gatiboni, L.C.; Brunetto, G.; Simonete, M.A.; Bicaratto, B. Eficiência Relativa de Fosfatos Naturais Na Adubação de Plantio de Mudas de Eucalyptus Dunnii Maiden e Eucalyptus Benthamii Maiden et Cambagem Em Solo Sem e Com Calagem. Ciência Florestal 2015, 25, 37-48. [CrossRef]

41. Rajamanickam, E.; Krishnapriya, V.; Pandey, R.; Rao, A.; Abrol, Y. Physiological and Molecular Approaches for Improving Phosphorus Uptake Efficiency of Crops. Curr. Sci. 2015, 108, 1271-1279.

42. Piccin, R.; Couto, R.D.R.; Bellinaso, R.J.S.; Gatiboni, L.C.; Conti, L.D.; Rodrigues, L.A.T.; Michelon, L.S.; Kulmann, M.S.D.S.; Brunetto, G. Phosphorus Forms in Leaves and Their Relationships with Must Composition and Yield in Grapevines. Pesquisa Agropecuária Brasileira 2017, 52, 319-327. [CrossRef]

43. Piccin, R.; Kaminski, J.; Ceretta, C.A.; Tiecher, T.; Gatiboni, L.C.; Bellinaso, R.J.S.; Marchezan, C.; Souza, R.O.S.D.; Brunetto, G. Distribution and Redistribution of Phosphorus Forms in Grapevines. Sci. Hortic. 2017, 218, 125-131. [CrossRef]

44. Gan, H.; Jiao, Y.; Jia, J.; Wang, X.; Li, H.; Shi, W.; Peng, C.; Polle, A.; Luo, Z.-B. Phosphorus and Nitrogen Physiology of Two Contrasting Poplar Genotypes When Exposed to Phosphorus and/or Nitrogen Starvation. Tree Physiol. 2016, 36, 22-38. [CrossRef]

45. Melo, E.; Gonçalves, J.; Rocha, J.; Hakamada, R.; Bazani, J.; Wenzel, A.; Arthur, J.; Borges, J.; Malheiros, R.; Lemos, C.; et al Responses of Clonal Eucalypt Plantations to N, P and K Fertilizer Application in Different Edaphoclimatic Conditions. Forests 2015, 7, 2. [CrossRef]

46. Talkner, U.; Meiwes, K.J.; Potočić, N.; Seletković, I.; Cools, N.; de Vos, B.; Rautio, P. Phosphorus Nutrition of Beech (Fagus sylvatica L.) Is Decreasing in Europe. Ann. For. Sci. 2015, 72, 919-928. [CrossRef] 